\title{
Job-Education Mismatch and Its Impact on the Earnings of Immigrants: Evidence from Recent Arrivals to Canada
}

\author{
Mesbah Fathy Sharaf \\ Department of Economics, Concordia University, 1455 de Maisonneuve Boulevard West, Montreal, QC, Canada H3G1MB
}

Correspondence should be addressed to Mesbah Fathy Sharaf; mesbah.sharaf@concordia.ca

Received 12 November 2012; Accepted 20 December 2012

Academic Editors: S. Rahman and A. Rodriguez-Alvarez

Copyright (C 2013 Mesbah Fathy Sharaf. This is an open access article distributed under the Creative Commons Attribution License, which permits unrestricted use, distribution, and reproduction in any medium, provided the original work is properly cited.

\begin{abstract}
Using the most recent Longitudinal Survey of Immigrants to Canada, this paper measures the incidence of job-education mismatch, particularly over-education, examines its determinants, and estimates its impact on the earnings of immigrants. Job-education mismatch is measured using the realized match method, and the corresponding earnings impact is estimated using an overrequired-under education technique. Determinants of over-education are examined using a bivariate probit model to account for selectivity into employment. Panel data estimation methods are used to estimate earnings equations and the analysis is stratified by gender. Results show that recent immigrants to Canada have a persistent high incidence and intensity of over-education with a substantial negative impact on their earnings. In particular, two-thirds of recent immigrants to Canada are over-educated with a wage loss of $8 \%$, while an under-educated immigrant loses around $2 \%$ on average. Results also show that proficiency in English or French and post-immigration investment in education and training significantly reduce the likelihood of being over-educated. The findings of this study could benefit policies directed to help immigrants integrate in the labour market.
\end{abstract}

\section{Introduction}

The contribution of immigrants to a host country's welfare largely depends on the degree to which their foreign education translates into useable qualifications and skills in the host labour market. A common finding is of the imperfect transferability of human capital across countries (see, e.g., [13]). New immigrants typically face barriers when searching for a job which, in principle, matches their qualifications. Such barriers either prevent or delay integration into the host labour market. In particular, immigrants who find a job on arrival in the host country usually work in a job which requires a level of education which is less than they actually possess. This form of job-education mismatch is known in the literature as over-education. If a worker is employed in a job requiring more years of schooling than the worker actually has, then the worker is under-educated. Most of the job-education mismatch literature focuses on studying over-education in view of its high incidence and significant adverse effects.
Several studies have examined the occupational outcomes of immigrants relative to their source-country educational attainment (see, e.g., $[2,4-6]$ ). The general finding is that there is a substantial earnings disadvantage and a high incidence of over-education among immigrants. For example, Li et al. [5] find that, during 1993-2001, 52\% of recent immigrants to Canada were over-educated compared to $28 \%$ of their Canadian-born counterparts; also recent immigrants are twice as likely to remain over-qualified compared to native Canadians. Using census data, Galarneau and Morissette [6] find that $28 \%$ of recent immigrant males and $40 \%$ of corresponding females, each with a university degree, were in jobs with lower educational requirements compared, respectively, to $10 \%$ and $12 \%$ for Canadianborn workers. Wald and Fang [7] find that half of the immigrants into Canada who arrived between 1989 and 1997 were over-educated. There is similar evidence from Europe: Nielsen [8] finds that the incidence of over-education among Danish immigrants with foreign-acquired education was $47 \%$ compared with $33 \%$ among native Danes. For additional 
international evidence, see: Lindley and Lenton [9] for the UK, Green et al. [2] and Kler [10] for Australia and Galarneau and Morissette [6] for Canada.

The adverse effects of over-education have been established in, for example, Galarneau and Morissette [6], Tsang and Levin [11], Tsang [12], Tsang et al. [13], Conference board of Canada [14]. For example, the Conference Board of Canada (2001) estimates that the Canadian economy loses up to 5 billion Canadian dollars per annum due to over-education. In addition, several theories have been put forward to explain the existence of over-education based on signaling from incomplete information [15]; spatial mobility [16]; differential over-qualification of secondary earners [17] and the human capital hypothesis. The most recent empirical literature on the incidence and impact of over-education is based on the human capital hypothesis. Immigrants are forced, initially on entering host-country labour market, to accept jobs with lower educational requirement to compensate for their lack of host-country-specific human capital. These include job experience, contacts in the host labour market, language skills, and social capital (e.g., from relatives and friends). Other reasons for over-education include poor quality of education, nonrecognition of foreign experience and credentials, market entry in a period of recession, and competition from domestic workers. The profile of personal characteristics of the immigrant also matters for being overeducated. The probability of being over-educated is expected to be high for immigrants who immigrate in old age or who are member of a visible minority. Mother tongue and country of origin are key reasons for an increased degree of over-education for recent and established immigrants to Canada [6]. Licensing requirements and regulations required by professional associations also play a role.

The main objective of this paper is to measure the incidence of job-education mismatches, particularly overeducation, to examine their main determinants and to estimate their corresponding impact on the earnings of recent immigrants to Canada. The extant literature in this area is mostly based on cross-sectional data or surveys. In this paper, longitudinal data are used from the most recent Longitudinal Survey of Immigrants to Canada (LSIC). Such data permit control of unobserved individual heterogeneity as well as the evolution of over-education, in particular, over time, leading to a more comprehensive analysis than hitherto. The paper proceeds as follows. Section 2 presents the empirical methodology followed, in Section 3, by a description of the data. The results are presented in Section 4 and discussed in Section 5. Finally, the conclusions are summarized in Section 6.

\section{Methodology}

2.1. Measuring the Job-Education Mismatch. A job-education mismatch for the $i$ th employed immigrant in occupation $j\left(i=1,2, \ldots, n_{j} ; j=1,2, \ldots, k ; \sum_{j} n_{j}=n\right)$ is measured as $\mathrm{O}_{i j}$ which is defined as

$$
O_{i j}=S_{i j}^{a}-S_{j}^{r}
$$

In which $S_{i j}^{a}$ is the actual years of schooling completed by employed immigrant $i$ in job $j, a S_{j}^{r}$ is the required years of schooling for job $j$. In job $j$, worker $i$ is over-educated if $S_{i j}^{a}>S_{j}^{r}$, under-educated if $S_{i j}^{a}<S_{j}^{r}$, and just-educated if $S_{i j}^{a}=S_{j}^{r}$. In addition to the $n$ employed immigrants, there are $m$ unemployed immigrants who are seeking employment and $(n+m)=N$.

Required schooling for each occupation $j$ is here defined as the modal number of years of schooling of the workers in occupation $j$. The arithmetic mean number of years could have been used yet the results are robust between the two [18].

2.2. Determinants of Over-Education. Being over-educated is observable only for those who are employed. Sampling only from the over-educated will generally lead to sample selection bias which can be avoided by allowing for the probability of selection into employment. This is achieved by applying a bivariate probit model with sample selection within which the probability of being over-educated, conditional on being employed, is estimated. The resulting estimates are consistent and asymptotically efficient $[19,20]$.

The first probit equation, (2) below, estimates the probability of being employed for each of $(n+m)=N$ immigrants, using $q$ explanatory factors listed in the appendix:

$$
\operatorname{Pr}\left(Y_{1}^{*}\right)=X \beta+u_{1}
$$

In which $\operatorname{Pr}\left(Y_{1}^{*}\right)$ is an $N \times 1$ vector representing $N$ probabilities of being employed, $X$ is a matrix of explanatory factors of order $N \times q, \beta$ is a $q \times 1$ vector of coefficients, and $u_{1}$ is a vector of residual errors of order $N \times 1$. The explanatory variables in the matrix $X$ include gender, age, marital status, immigration class, level of education, region of origin, field of study, language proficiency, visible minority status, whether foreign work experience is recognized in the Canadian labour market. In addition, to account for the effect of any postimmigration investments in Canadian human capital, a set of dummy variables that indicate whether the immigrant has a Canadian work experience or has taken any education or training after arrival are used.

The probability of being employed $\left(Y_{1 i}^{*}\right)$ is latent, but what is observed is a dichotomous variable $\left(Y_{1 i}\right)$ indicating whether the individual $i$ is employed or not, such that

$$
\begin{array}{ll}
Y_{1 i}=1 & \text { if } Y_{1 i}^{*}>0 \\
Y_{1 i}=0 & \text { otherwise. }
\end{array}
$$

The second probit equation, (4) below, estimates the probability of being over-educated for each of $n$ employed immigrants as follows:

$$
\operatorname{Pr}\left(Y_{2}^{*}\right)=Z \alpha+u_{2}
$$

In which $\operatorname{Pr}\left(Y_{2}^{*}\right)$ is an $n \times 1$ vector representing $n$ probabilities of being over-educated, $Z$ is a matrix of explanatory factors of order $n \times r, \alpha$ is a $r \times 1$ vector of coefficients, and $u_{2}$ is an $n \times 1$ vector of residual errors. The matrix $Z$ includes most of the explanatory variables included in the first probit equation in 
addition to the number of education credentials and whether the job is part time or full time. $Y_{2 i}^{*}$ is also latent, but what is observed is a dichotomous variable $\left(Y_{2 i}\right)$ for whether the individual $i$ is over-educated or not, such that

$$
\begin{array}{ll}
Y_{2 i}=1 & \text { if } Y_{1 i}^{*}>0, \\
Y_{2 i}=0 & \text { otherwise. }
\end{array}
$$

The error term in each of the probit equation is specified as follows:

$$
\begin{gathered}
u_{1 i}=\eta_{i}+\epsilon_{1 i}, \\
u_{2 i}=\eta_{i}+\epsilon_{2 i}, \\
\operatorname{cov}\left(u_{1 i}, u_{2 i}\right)=\rho, \quad \text { where } \rho \neq 0, \\
\left(u_{1 i}, u_{2 i}\right) \sim \text { bivariate normal. }
\end{gathered}
$$

The error terms $u_{1 i}$ and $u_{2 i}$ consist of a part $\epsilon_{i}$ that is specific to that equation and a second part $\eta_{i}$ that is common to both equations. This means that the error terms in the two probit equations may be correlated due to the existence of unobserved factors that jointly affect the probability of employment and over-education. The correlation between the two error terms is estimated and tested for its statistical significance. If $\rho \neq 0$, the standard probit method applied only to the over-education equation produces biased results. However, the biprobit model with sample selection gives consistent and asymptotically efficient estimates [19, 20].

The objective is to estimate the probability of an immigrant being over-educated conditional on being employed, which is given by

$$
\operatorname{pr}\left(Y_{2 i}=1 \mid Y_{1 i}=1\right)=\operatorname{pr}\left(u_{2 i}>-Z_{i} \beta u_{2 i}>-X_{i} \beta\right) .
$$

The joint estimation of (2) and (4), the testing of the correlation of corresponding estimates of $u_{1}$ and $u_{2}$, and the estimation of the probability of over-education conditional on being employed are all undertaken using the biprobit model in STATA 11.

2.3. The Earnings Impact of Job-Education Mismatches. The impact of job-education mismatch on earnings is estimated using the over-required-under education (ORU) model [18]. It has been shown that the ORU model is superior to the conventional Mincerian earnings function which uses total schooling as an explanatory variable. The standard earnings function may give misleading results, because the return to surplus schooling-beyond what is required by the job-is likely to be lower than the return to required schooling [21].

The ORU model may be presented as follows:

$$
\begin{gathered}
S_{i j t}^{T}=S_{j t}^{r}+S_{i j t}^{o}-S_{i j t}^{u} \\
\operatorname{Ln} w_{i j t}=\beta_{0}+\beta_{1} X_{i j t}+\beta_{2} S_{j t}^{r}+\beta_{3} S_{i j t}^{o}+\beta_{4} S_{i j t}^{u}+u_{i j t} .
\end{gathered}
$$

The subscripts $i, j$, and $t$ index, respectively, individual, occupation, and time period. $S^{r}$ denotes required years of schooling by the job, $S^{o}$ denotes years of over-education, and $S^{u}$ denotes years of under-education. $X_{i j t}$ is a vector of control variables: age, gender, field of study, marital status, immigration class, work experience, language proficiency, provincial dummies, and visible minority status. $u_{i j t}$ is the standard time varying residual term. It should be noted that $S^{o}$ and $S^{u}$ are mutually exclusive, and for each individual, one of them or both must be zero. The ORU model is reduced to the standard Mincerian earning equation if $\beta_{2}=\beta_{3}=\left|\beta_{4}\right|$. However, if this does not hold, the ORU model will yield a better fit and the return to required education will be greater than the return to total education [21].

Under the ORU model, over-educated and under-educated workers are compared to coworkers, that is, workers with the same required schooling who are just-educated. Accordingly, the coefficients in the ORU model are interpreted as follows:

$\beta_{2}$ : return to an additional year of required schooling, $\beta_{3}$ : return to an additional year of surplus schooling relative to coworkers,

$\beta_{4}$ : wage loss of an additional year of deficit schooling relative to coworkers,

$\beta_{3}-\beta_{2}$ : return to an additional year of surplus schooling relative to workers, and with the same total year of schooling which is adequately used.

Several findings concerning the earnings impact of jobeducation mismatch are documented in the literature (see: $[18,22-25])$. First, the return to over-education is positive $\left(\beta_{3}>0\right)$ but smaller than required education $\left(\beta_{3}<\beta_{2}\right)$, while the return to under-education is negative $\left(\beta_{4}<0\right)$. Second, over-educated workers earn less than workers with the same educational attainment in jobs which require that level of schooling $\left(\beta_{3}-\beta_{2}\right)<0$. However, under-educated workers earn more than workers with the same educational level working in jobs requiring the level of education that they have, and earn less than coworkers possessing the required level of education.

As a baseline model, (9) is estimated by a pooled crosssectional method, using ordinary least square (OLS), with standard errors corrected for clustering at the individual level. Pooled OLS produces consistent estimators, if the error term in the ORU model is uncorrelated with the explanatory variables in the model. However, if unobserved individual characteristics are crucial for determining earnings, then the error term will be correlated with the included explanatory variables, and hence it is better to use panel data estimation methods to yield consistent estimates. To benefit from the longitudinal structure of the LSIC in accounting for unobserved individual heterogeneity, (9) may be estimated using panel data methods, using both of the between effects and random effects models. The between effect is obtained when OLS is performed on the average over time for each individual in (9). The fixed effects model is also estimated but is not reported, because the key variables of interest were dropped in the fixed effects estimation. Accordingly, (9) can be rewritten as

$$
\operatorname{Ln} w_{i j t}=\beta_{0}+\beta_{1} X_{i t}+\beta_{2} S_{j t}^{r}+\beta_{3} S_{i j t}^{o}+\beta_{4} S_{i j t}^{u}+\mu_{i}+v_{i j t} .
$$


Here, the error term $u_{i j t}$, from (9) becomes $\mu_{i}+v_{i j t}$, where $\mu_{i}$ represents time invariant individual-specific effects and $v_{i j t}$ is the standard residual term. In the random effects model, $\mu_{i}$ is assumed to be uncorrelated with other covariates in the model [19]. STATA 11 software package is used to conduct the multivariate analyses, and all the estimation as well as the calculations of (2) and (4) are weighted using the LSIC sampling weights.

\section{Data and Sample Characteristics}

The main data source for this study is the LSIC. The survey was conducted by Statistics Canada and Citizenship and Immigration Canada using a sample from the 164,200 immigrants who immigrated to Canada between October 2000 and September 2001. The survey consists of three waves of interviews of the same cohort of immigrants. In the first wave, 12,000 immigrants aged 15 years and above were interviewed between April 2001 and May 2002, six months after becoming permanent residents in Canada. In the second wave, 9,300 of the same immigrants were interviewed in 2003, two years after landing. In 2005, about 7,700 of the same immigrants were reinterviewed, four years after their arrival. The LSIC contains comprehensive information on all standard labour market and sociodemographic variables. For more information about the LSIC see Statistics Canada [26].

To achieve the objectives of the current study, data from the three waves of the LSIC survey are used. Data from the confidential 2001 Canadian census of population is used to derive the required years of schooling based on 508 occupations which, in each occupation, is determined by the modal number of years of schooling of workers in that particular occupation.

The multivariate analyses include a number of economic and sociodemographic variables commonly used in the literature. Age is represented in continuous form. Gender is captured by two dummy variables. Marital status is represented by two dummy variables: married, single, or separated. An individual's educational attainment is captured by the total number of years of schooling. Work experience in the Canadian labour market is captured by the number of weeks that an immigrant has worked in Canada. Foreign work experience has two specifications. In the first specification, a dummy variable is used to indicate whether the immigrant had full-time foreign-work experience before immigration. In the second specification, potential work experience (age minus years of schooling minus 6) is used. Immigration class is captured by four categories: family class, skilled workers, business class (reference group), and refugees. Provincial or regional fixed effects are represented in five categories: Ontario, Quebec, British Colombia (reference group), Atlantic provinces (New Brunswick, Prince Edward Island, Nova Scotia and Newfoundland and Labrador), and Western provinces (Alberta, Saskatchewan and Manitoba). Immigrants' fields of study appear as seven categories: educational; fine arts, humanities and social sciences; engineering; health professions; commerce (reference group); agriculture and mathematics; and no specialization. Language proficiency is captured by an indicator variable: English/French is the mother tongue and English/French is not the mother tongue (reference group). Experience recognition is captured by an indicator variable with foreign experience not recognized in the Canadian labour market as the reference group. Working status comes as full time (1), part time (0). The analysis also includes a dichotomous variable indicating whether an individual belongs to a visible minority (1) group as defined by Statistics Canada or not (0).

Table 1 reports the summary statistics of the variables included in the analysis. Half of the immigrants are males, $80 \%$ are married, $60 \%$ have at least a bachelor degree, and $61.3 \%$ are skilled workers. For the field of study, $17.3 \%$ have an engineering background, and 19\% are in commerce or management-related fields. $9.5 \%$ of the immigrants reported English or French as their mother tongue. $48 \%$ are residing in Ontario. The average age of individuals in the sample is 35 years.

\section{Empirical Findings}

4.1. The Incidence and Intensity of the Job-Education Mismatch. The longitudinal feature of the LSIC facilitates the study of how the incidence and intensity of over-education has evolved over time. The incidence of the job-education mismatch at each wave of the LSIC is reported in Table 2. The results indicate a high incidence of over-education among recent immigrants to Canada since $76.3 \%$ of the immigrant males and $71.8 \%$ of the females is over-educated in the first wave of the LSIC ( 6 months after becoming permanent residents). These figures did not improve much after four years from arrival, when $70.4 \%$ of the males and $64.6 \%$ of the females are over-educated. The results also indicate that $15.7 \%$ of the immigrant males and $16.6 \%$ of the females are under-educated after 6 months from arrival in Canada. As a benchmark for comparison purpose, the incidence of over-education among Canadian-born is estimated as $43.85 \%$ using data from the 2001 Canadian census.

The persistent high incidence of over-education among recent immigrants is in line with the findings of several previous studies which examined earlier cohorts of immigrants to Canada (e.g., $[4,5,7]$ ).

The wide range of variables in the LSIC enables measuring the incidence of job-education mismatches among different subgroups of immigrants. Accordingly, the sample is stratified by gender, marital status, age, and level of education.

Table 3 shows considerable differences in the incidence of over-education among different subgroups of immigrants. Based on the LSIC data, the incidence of over-education is higher among recent immigrant males than among females, and is also higher among married people than singles. The incidence of over-education decreases with age. This is consistent with the job search behavior of young workers and the fact that young workers lack enough job experience or training, relative to older workers.

Not surprisingly, the incidence of over-education increases with educational attainment. The results show that immigrants with a high level of education face substantial difficulties in transferring their qualifications to the Canadian labour market than the less educated immigrants. For 
TABle 1: Descriptive statistics.

Variables

Age (years)

Male (1 if yes, zero if no)

Female ( 1 if yes, zero if no)

Married (1 if yes, zero if no)

Highest level of educational attainment

Less than high school (1 if yes, zero if no)

High school ( 1 if yes, zero if no)

Some college ( 1 if yes, zero if no)

College (1 if yes, zero if no)

Bachelor degree (1 if yes, zero if no)

Graduate degree (1 if yes, zero if no)

Degree in dentistry, medicine, veterinary medicine, optometry, law, or theology ( 1 if yes, zero if no)

English or French is the mother tongue (1 if yes, zero if no)

Visible minority ( 1 if yes, zero if no)

Field of study

Educational, recreational and counseling services

Fine and applied arts

Humanities and related fields

Social sciences and related fields

Commerce, management and business administration

Agricultural and biological sciences and technologies

Engineering and applied sciences

Health professions, sciences and technologies

Mathematics and physical sciences

Immigration category

Family class ( 1 if yes, zero if no)

Skilled workers (1 if yes, zero if no)

Business class ( 1 if yes, zero if no)

Refugees (1 if yes, zero if no)

Provincial nominees ( 1 if yes, zero if no)

Province of residence

Quebec

Ontario

Western provinces

Atlantic provinces

British Columbia

Host country human capital

Postimmigration education or training in Canada ( 1 if yes, zero if no)

Has Canadian work experience (1 if yes, zero if no)

Working Part Time (1 if yes, zero if no)

Source country human capital

Has full time Foreign work experience ( 1 if yes, zero if no)

Foreign experience recognized ( 1 if yes, zero if no)

Has credentials

Number of credentials

Mean

35.3

49.38

50.62

80.02

11.9

5.4

10.1

17.5

1.2

9.49

83.4

6.3

2.07

5.4

7.4

19.4

2.3

17.3 3

5.4

26.90

61.29

5.8

4.58

0.88

15.24

48.07

14.91

1.21

20.57

58.9

69.4

Source: Longitudinal Survey of Immigrants to Canada. Statistics are weighted using LSIC sampling weight. These summary statistics are calculated using the balanced sample of immigrants who were interviewed at the three waves of interviews. 
TABLE 2: The incidence of job-education mismatches among recent immigrants to Canada.

\begin{tabular}{|c|c|c|c|c|c|c|}
\hline & \multicolumn{3}{|c|}{ Males } & \multicolumn{3}{|c|}{ Females } \\
\hline & Wave 1 & Wave 2 & Wave 3 & Wave 1 & Wave 2 & Wave 3 \\
\hline Overeducated & 76.27 & 72.51 & 70.35 & 71.76 & 68.89 & 64.61 \\
\hline Justeducated & 8.02 & 9.18 & 9.65 & 11.69 & 11.79 & 12.97 \\
\hline Undereducated & 15.71 & 18.31 & 20 & 16.55 & 19.32 & 22.42 \\
\hline
\end{tabular}

Source: author's calculation using data from LSIC. All statistics are population weighted using the LSIC sampling weights.

TABLE 3: The incidence of over-education among different subgroups of immigrants (\% of each relevant group that is over-educated).

\begin{tabular}{|c|c|c|c|}
\hline & Wave 1 & Wave 2 & Wave 3 \\
\hline \multicolumn{4}{|l|}{ Gender } \\
\hline Male & 76.27 & 72.51 & 70.35 \\
\hline Female & 71.76 & 68.89 & 64.61 \\
\hline \multicolumn{4}{|l|}{ Marital status } \\
\hline Married & 77.31 & 75.89 & 72.20 \\
\hline Not married & 59.35 & 49.40 & 48.04 \\
\hline \multicolumn{4}{|l|}{ Age } \\
\hline $25-34$ & 82.25 & 81.39 & 75.01 \\
\hline $35-44$ & 81.77 & 79.57 & 76.34 \\
\hline $45-54$ & 62.05 & 60.67 & 64.36 \\
\hline $55-64$ & 41.24 & 47.05 & 48.21 \\
\hline \multicolumn{4}{|l|}{ Highest level of education } \\
\hline Some elementary or elementary & 2.51 & 1.48 & 1.79 \\
\hline Some high school & 7.01 & 3.73 & 2.81 \\
\hline High school graduation & 20.97 & 19.66 & 16.80 \\
\hline Some trade or apprenticeship training & 56.08 & 52.24 & 51.38 \\
\hline Trade certificate & 60.87 & 54.73 & 58.47 \\
\hline Some college & 66.22 & 67.77 & 61.68 \\
\hline College/CEGEP & 76.56 & 77.09 & 75.25 \\
\hline Some university & 85.53 & 83.03 & 79.95 \\
\hline Bachelor's degree & 90.92 & 89.62 & 82.67 \\
\hline Master's degree & 94.35 & 92.90 & 87.09 \\
\hline Degree in medicine or law & 95.72 & 96.60 & 89.52 \\
\hline Doctorate & 87.30 & 90.71 & 86.86 \\
\hline
\end{tabular}

Source: author's compilation using data from LSIC. All statistics are population weighted using the LSIC sampling weights.

example, $90 \%$ of recent immigrants with a bachelor degree, and $94 \%$ with a master degree are over-educated. Immigrants with a degree in regulated occupations such as dentistry, medicine, veterinary medicine, optometry, and law have the highest incidence of over-education at 96\%. These findings are consistent across the three waves of the LSIC and are in line with the findings of Li et al. [5], Wald and Fang [7].

A complete understanding of the phenomenon of overeducation and under-education requires studying not only its incidence but also its intensity (how many years of surplus or deficit schooling), and how each evolves over time. Studying how the job-education mismatch intensity evolves over time helps in understanding the dynamics of the assimilation process, where a reduction in the intensity of the job-education mismatch could be an indicator of job match improvement and assimilation. The general finding from this analysis is that the incidence and intensity of over-education decreases with the length of stay in Canada (see Table 4).

The distribution of job-education mismatch intensity and its evolution by the length of stay in Canada are shown in Figures 1, 2, and 3. The distribution is clearly not symmetric, but it is negatively skewed. Thus the left tail is longer, with a few negative values (under-educated), the mass of the distribution being concentrated on the right (over-educated). However, the skewness of the distribution has decreased according to the time spent in Canada.

4.2. Determinants of Over-Education. Results from the bivariate probit model for the determinants of employment and over-education are presented in Table 5.

Results show that recent immigrants who are members of a visible minority are less likely to be employed and more likely to be over-educated. This is consistent with the findings 


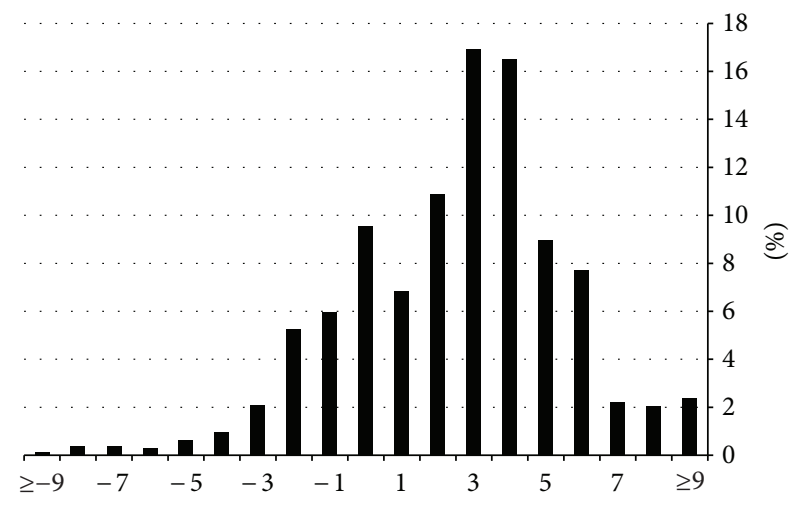

\begin{tabular}{|c|c|c|c|}
\hline Mean & Standard deviation & Skewness & Kurtosis \\
\hline 2.54 & 3.11 & -0.169 & 4.33 \\
\hline
\end{tabular}

FIGURE 1: Distribution of job-education mismatches intensity after six months from arrival to Canada. Source: the distribution is based on data from Table 4.

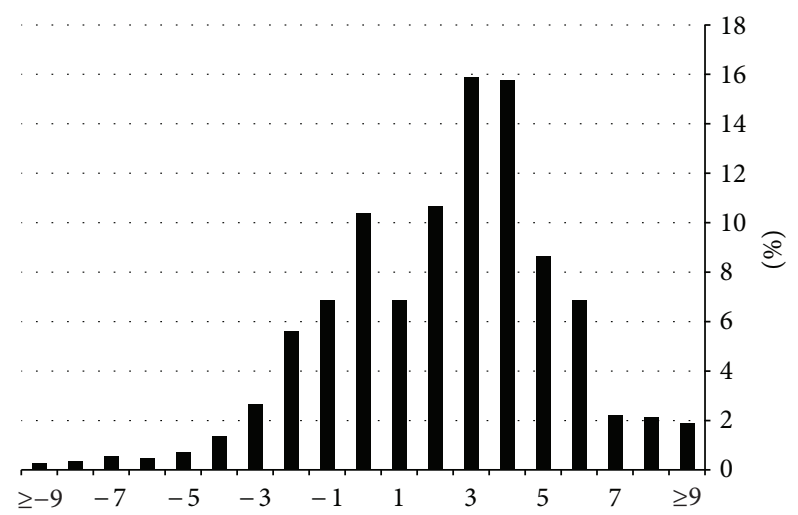

\begin{tabular}{|c|c|c|c|}
\hline Mean & Standard deviation & Skewness & Kurtosis \\
\hline 2.29 & 3.24 & -0.158 & 4.83 \\
\hline
\end{tabular}

FIGURE 2: Distribution of job-education mismatches intensity after two years from arrival to Canada. Source: the distribution is based on data from Table 4.

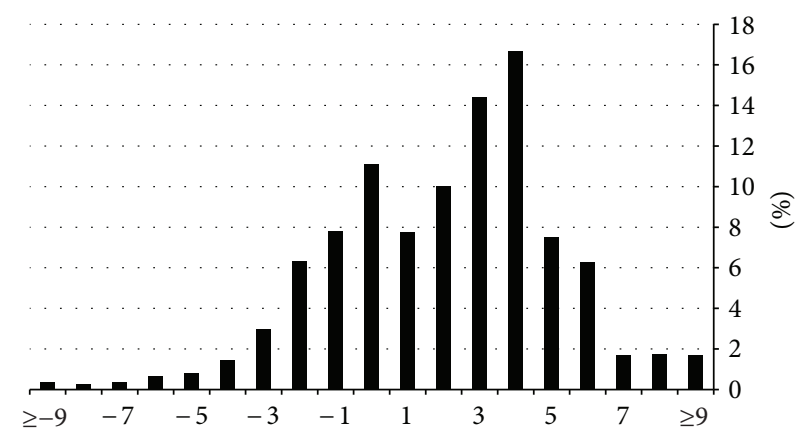

\begin{tabular}{|c|c|c|c|}
\hline Mean & Standard deviation & Skewness & Kurtosis \\
\hline 2.05 & 3.22 & -0.195 & 4.54 \\
\hline
\end{tabular}

FIGURE 3: Distribution of job-education mismatches intensity after four years from arrival to Canada. Source: the distribution is based on data from Table 4.
TABLE 4: Distribution of the job-education mismatches intensity (\% of immigrants).

\begin{tabular}{lccc}
\hline Intensity & Wave 1 & Wave 2 & Wave 3 \\
\hline$\geq 9$ & 2.36 & 1.9 & 1.69 \\
8 & 2.03 & 2.11 & 1.74 \\
7 & 2.21 & 2.208 & 1.72 \\
6 & 7.7 & 6.86 & 6.282 \\
5 & 8.952 & 8.63 & 7.506 \\
4 & 16.51 & 15.77 & 16.66 \\
3 & 16.92 & 15.9 & 14.43 \\
2 & 10.86 & 10.64 & 10.02 \\
1 & 6.85 & 6.85 & 7.781 \\
0 & 9.55 & 10.37 & 11.11 \\
-1 & 5.96 & 6.88 & 7.803 \\
-2 & 5.24 & 5.6 & 6.353 \\
-3 & 2.093 & 2.674 & 3 \\
-4 & 0.975 & 1.345 & 1.445 \\
-5 & 0.607 & 0.6922 & 0.82 \\
-6 & 0.3 & 0.458 & 0.67 \\
-7 & 0.38 & 0.53 & 0.35 \\
-8 & 0.38 & 0.33 & 0.25 \\
$\geq-9$ & 0.13 & 0.25 & 0.35 \\
\hline S & & &
\end{tabular}

Source: author's compilation. All statistics are population weighted using the LSIC sampling weights.

of several studies which reveal that immigrants may be subject to discrimination in the Canadian labour market (e.g., $[4,7])$. Previous studies show that language proficiency and region of origin are important determinants of employment and over-education. Consistent with these findings, results of the biprobit model show that immigrants with excellent or well-established English or French proficiency are more likely to be employed and less likely to be over-educated relative to immigrants with poor language ability. Results also show that post-immigration education and training increase the probability of employment and reduce the probability of being over-educated. This is known in the assimilation literature as the time since immigration effect. As immigrants stay more in the host country and start to accumulate hostcountry-specific human capital, their labour market outcome is expected to improve. Having relatives in Canada increases the chances of being employed, showing the importance of social capital in helping immigrants to integrate. As recognition of the importance of social capital, the immigration point system in Canada gives 5 points for having relatives in Canada. Also the likelihood of employment increases with age where older workers are expected to have more accumulated human capital to offer in the labour market. Married immigrants are less likely to be employed and overeducated, relative to single immigrants. The recognition of foreign work experience in the Canadian labour market decreases the probability of being over-educated. Part-time job holders are more likely to be over-educated. As the number of credentials increases, the probability of overeducation increases, because it will be longer and more costly 
TABLE 5: Results of the bivariate probit regression-determinants of employment and over-education of immigrants aged 15-64.

\begin{tabular}{|c|c|c|}
\hline & Probability employed & Probability overeducated \\
\hline \multicolumn{3}{|l|}{ Demographic factors } \\
\hline \multirow{2}{*}{ Age $25-34$} & $1.075^{* * *}$ & $0.222^{* * *}$ \\
\hline & $(0.0185)$ & $(0.0428)$ \\
\hline \multirow{2}{*}{ Age $35-44$} & $1.129^{* * *}$ & $0.309^{* * *}$ \\
\hline & $(0.0189)$ & $(0.0429)$ \\
\hline \multirow{2}{*}{ Age $45-64$} & $0.854^{* * *}$ & $0.473^{* * *}$ \\
\hline & $(0.0185)$ & $(0.0381)$ \\
\hline \multirow{2}{*}{ Male } & $0.502^{* * *}$ & $0.259^{* * *}$ \\
\hline & $(0.00869)$ & $(0.0128)$ \\
\hline \multirow{2}{*}{ Married } & $-0.0640^{* * *}$ & $-0.0341^{* *}$ \\
\hline & $(0.0127)$ & $(0.0134)$ \\
\hline \multicolumn{3}{|l|}{ Educational attainment } \\
\hline \multirow{2}{*}{ College } & $0.908^{* * *}$ & $0.459^{* * *}$ \\
\hline & $(0.0137)$ & $(0.0278)$ \\
\hline \multirow{2}{*}{ Bachelor } & $0.950^{* * *}$ & $0.638^{* * *}$ \\
\hline & $(0.0122)$ & $(0.0255)$ \\
\hline \multirow{2}{*}{ Graduate } & $0.891^{* * *}$ & $0.547^{* * *}$ \\
\hline & $(0.0143)$ & $(0.0262)$ \\
\hline \multicolumn{3}{|l|}{ Immigration class } \\
\hline \multirow{2}{*}{ Family class } & $-0.269^{* * *}$ & $0.0545^{* * *}$ \\
\hline & $(0.0140)$ & $(0.0148)$ \\
\hline \multirow{2}{*}{ Skilled workers } & $-0.0367^{* * *}$ & $0.144^{* * *}$ \\
\hline & $(0.0104)$ & $(0.0106)$ \\
\hline \multirow{2}{*}{ Business class } & $-0.107^{* * *}$ & $-0.0444^{*}$ \\
\hline & $(0.0194)$ & $(0.0234)$ \\
\hline \multicolumn{3}{|l|}{ Country of origin } \\
\hline \multirow{2}{*}{ Europe } & $0.168^{* * *}$ & $0.352^{* * *}$ \\
\hline & $(0.0246)$ & $(0.0246)$ \\
\hline \multirow{2}{*}{ Asia } & 0.0213 & $0.240^{* * *}$ \\
\hline & $(0.0231)$ & $(0.0234)$ \\
\hline \multirow{2}{*}{ Middle East } & $-0.106^{* * *}$ & 0.0401 \\
\hline & $(0.0266)$ & $(0.0280)$ \\
\hline \multirow{2}{*}{ Africa } & $-0.219^{* * *}$ & $0.235^{* * *}$ \\
\hline & $(0.0259)$ & $(0.0276)$ \\
\hline \multirow{2}{*}{ Caribbean and Guyana } & $0.0643^{*}$ & $0.294^{* * *}$ \\
\hline & $(0.0352)$ & $(0.0369)$ \\
\hline \multirow{2}{*}{ South and Central America } & $0.165^{* * *}$ & 0.0428 \\
\hline & $(0.0327)$ & $(0.0332)$ \\
\hline \multirow{2}{*}{ Oceania and Australia } & $0.251^{* * *}$ & $0.192^{* * *}$ \\
\hline & $(0.0584)$ & $(0.0549)$ \\
\hline \multicolumn{3}{|l|}{ Province of residence } \\
\hline Ouebec & $-0.475^{* * *}$ & $-0.184^{* * *}$ \\
\hline Quedec & $(0.0154)$ & $(0.0192)$ \\
\hline Ontario & $0.0616^{* * *}$ & $0.265^{* * *}$ \\
\hline Untario & $(0.0114)$ & $(0.0125)$ \\
\hline Atlantic & $0.187^{* * *}$ & $0.0949^{*}$ \\
\hline Atlantic & $(0.0476)$ & $(0.0495)$ \\
\hline Western & $0.241^{* * *}$ & $0.0448^{* * *}$ \\
\hline Western & $(0.0164)$ & $(0.0170)$ \\
\hline
\end{tabular}


TABle 5: Continued.

\begin{tabular}{|c|c|c|}
\hline & Probability employed & Probability overeducated \\
\hline \multicolumn{3}{|l|}{ Language ability } \\
\hline Excellent and very good & $\begin{array}{l}0.439^{* * *} \\
(0.0106)\end{array}$ & $\begin{array}{c}-0.138^{* * *} \\
(0.0157)\end{array}$ \\
\hline well & $\begin{array}{l}0.162^{* * *} \\
(0.0104)\end{array}$ & $\begin{array}{c}-0.0470^{* * *} \\
(0.0127)\end{array}$ \\
\hline \multicolumn{3}{|l|}{ Field of study } \\
\hline Educational & & $\begin{array}{l}0.0273^{*} \\
(0.0163)\end{array}$ \\
\hline Fine arts, humanities and social science & & $\begin{array}{c}0.0680^{* * *} \\
(0.0125)\end{array}$ \\
\hline No specialization & & $\begin{array}{c}-0.0322^{* *} \\
(0.0164)\end{array}$ \\
\hline Agriculture and mathematics & & $\begin{array}{c}-0.0867^{* * *} \\
(0.0151)\end{array}$ \\
\hline Engineering & & $\begin{array}{c}0.0940^{* * *} \\
(0.0119)\end{array}$ \\
\hline Health & & $\begin{array}{l}-0.0250 \\
(0.0222)\end{array}$ \\
\hline Took education & $\begin{array}{l}0.0407^{* * *} \\
(0.00889)\end{array}$ & $\begin{array}{c}-0.0662^{* * *} \\
(0.00933)\end{array}$ \\
\hline Foreign experience is recognized & $\begin{array}{l}0.484^{* * *} \\
(0.0121)\end{array}$ & $\begin{array}{c}-0.248^{* * *} \\
(0.0142)\end{array}$ \\
\hline Visible minority & $\begin{array}{c}-0.0379^{* *} \\
(0.0158)\end{array}$ & $\begin{array}{l}0.160^{* * *} \\
(0.0163)\end{array}$ \\
\hline Number of credentials & & $\begin{array}{l}0.0400^{* * *} \\
(0.00507)\end{array}$ \\
\hline Part time & & $\begin{array}{l}0.195^{* * *} \\
(0.0128)\end{array}$ \\
\hline Arranged employment & $\begin{array}{l}0.749^{* * *} \\
(0.0253)\end{array}$ & \\
\hline Relatives in Canada & $\begin{array}{l}0.121^{* * *} \\
(0.0105)\end{array}$ & \\
\hline Constant & $\begin{array}{c}-1.864^{* * *} \\
(0.0328)\end{array}$ & $\begin{array}{c}-1.793^{* * *} \\
(0.0794)\end{array}$ \\
\hline Rho & & $\begin{array}{l}0.59^{* * *} \\
(0.040)\end{array}$ \\
\hline Observations & 134473 & 134473 \\
\hline
\end{tabular}

Robust standard errors are in parentheses, ${ }^{* * *} P<0.01,{ }^{* *} P<0.05,{ }^{*} P<0.1$.

Source: author's compilation.

to recognize them. These results are in line with the findings of Li et al. [5] using the Canadian Survey of Labour and Income Dynamics.

Note that the correlation coefficient between the two error terms is positive and statistically significant, suggesting that sample selection is a significant problem, and that there are unobserved factors that jointly affect the likelihood of employment and over-education. This means that the standard probit model applied only to the over-education equation produces biased results. However, as indicated earlier in the paper, the biprobit model with sample selection yields consistent and asymptotically efficient estimates.
4.3. The Earnings Impact of the Job-Education Mismatch. Results from estimating the ORU earnings equation are reported in Table 6 for the whole population. In addition, the results for males and females are reported in Table 7.

Consistent with previous findings, the return to overeducation is positive, but smaller than the returns to required education for both males and females, while the return to under-education is negative. These findings are robust to changing the model specification and estimation method. Given that the results of the three estimation methods pooled OLS, random effects and between effects are very similar, results obtained from the pooled OLS model have been 
TABle 6: The earnings impact of job-education mismatch-whole population.

\begin{tabular}{|c|c|c|c|}
\hline & OLS & $\mathrm{RE}$ & $\mathrm{BE}$ \\
\hline \multirow{2}{*}{ Years of required education } & $0.108^{* * *}$ & $0.105^{* * *}$ & $0.115^{* * *}$ \\
\hline & $(0.00746)$ & $(0.00609)$ & $(0.00752)$ \\
\hline \multirow{2}{*}{ Years of over-education } & $0.0264^{* * *}$ & $0.0241^{* * *}$ & $0.0223^{* * *}$ \\
\hline & $(0.00525)$ & $(0.00536)$ & $(0.00585)$ \\
\hline \multirow{2}{*}{ Years of under-education } & $-0.0214^{* * *}$ & $-0.0206^{* *}$ & $-0.0192^{* *}$ \\
\hline & $(0.00789)$ & $(0.00808)$ & $(0.00859)$ \\
\hline \multirow{2}{*}{ Age } & $0.0384^{* * *}$ & $0.0429^{* * *}$ & $0.0348^{* * *}$ \\
\hline & $(0.00872)$ & $(0.00729)$ & $(0.00802)$ \\
\hline \multirow{2}{*}{ Age square } & $-0.000489^{* * *}$ & $-0.000521^{* * *}$ & $-0.000438^{* * *}$ \\
\hline & $(0.000115)$ & $(9.04 e-05)$ & $(9.94 e-05)$ \\
\hline \multirow{2}{*}{ Visible minority } & $-0.0658^{* * *}$ & $-0.0561^{* *}$ & -0.0416 \\
\hline & $(0.0251)$ & $(0.0272)$ & $(0.0280)$ \\
\hline \multirow{2}{*}{ English/French is mother tongue } & $0.170^{* * *}$ & $0.176^{* * *}$ & $0.174^{* * *}$ \\
\hline & $(0.0370)$ & $(0.0362)$ & $(0.0382)$ \\
\hline \multirow{2}{*}{ Full time foreign experience } & 0.0280 & 0.00462 & 0.0301 \\
\hline & $(0.0267)$ & $(0.0310)$ & $(0.0321)$ \\
\hline \multirow{2}{*}{ Foreign experience is recognized } & $0.279^{* * *}$ & $0.292^{* * *}$ & $0.283^{* * *}$ \\
\hline & $(0.0239)$ & $(0.0263)$ & $(0.0281)$ \\
\hline \multirow{2}{*}{ Married } & 0.0252 & 0.0213 & 0.0467 \\
\hline & $(0.0298)$ & $(0.0303)$ & $(0.0317)$ \\
\hline \multirow{2}{*}{ Part time } & $-0.978^{* * *}$ & $-0.975^{* * *}$ & $-0.995^{* * *}$ \\
\hline & $(0.0292)$ & $(0.0210)$ & $(0.0313)$ \\
\hline \multirow{2}{*}{ Experience in Canada } & $0.00375^{* * *}$ & $0.00367^{* * *}$ & $0.00431^{* * *}$ \\
\hline & $(0.000241)$ & $(0.000201)$ & $(0.000493)$ \\
\hline \multirow{2}{*}{ Education and recreational } & -0.0442 & $-0.0926^{*}$ & $-0.100^{*}$ \\
\hline & $(0.0489)$ & $(0.0493)$ & $(0.0514)$ \\
\hline \multirow{2}{*}{ Fine art } & -0.00152 & -0.0730 & -0.0668 \\
\hline & $(0.144)$ & $(0.0899)$ & $(0.0902)$ \\
\hline \multirow{2}{*}{ Humanities } & -0.0532 & -0.0362 & -0.00256 \\
\hline & $(0.0521)$ & $(0.0528)$ & $(0.0546)$ \\
\hline \multirow{2}{*}{ Social sciences } & -0.0375 & -0.0527 & -0.0493 \\
\hline & $(0.0414)$ & $(0.0470)$ & $(0.0488)$ \\
\hline \multirow{2}{*}{ Commerce } & 0.00567 & -0.00140 & 0.00446 \\
\hline & $(0.0294)$ & $(0.0357)$ & $(0.0371)$ \\
\hline \multirow{2}{*}{ Agriculture } & -0.112 & -0.0736 & -0.0148 \\
\hline & $(0.0718)$ & $(0.0775)$ & $(0.0799)$ \\
\hline \multirow{2}{*}{ Engineering } & 0.0292 & 0.00780 & 0.0103 \\
\hline & $(0.0302)$ & $(0.0367)$ & $(0.0382)$ \\
\hline \multirow{2}{*}{ Health } & -0.0200 & -0.0321 & -0.0583 \\
\hline & $(0.0566)$ & $(0.0679)$ & $(0.0704)$ \\
\hline \multirow{2}{*}{ Mathematics } & $0.190^{* * *}$ & $0.171^{* * *}$ & $0.171^{* * *}$ \\
\hline & $(0.0536)$ & $(0.0522)$ & $(0.0543)$ \\
\hline \multirow{2}{*}{ Family class } & -0.000245 & -0.0236 & -0.0571 \\
\hline & $(0.0566)$ & $(0.0521)$ & $(0.0527)$ \\
\hline \multirow{2}{*}{ Skilled workers } & -0.00710 & -0.0176 & -0.0409 \\
\hline & $(0.0555)$ & $(0.0507)$ & $(0.0510)$ \\
\hline Provincial nominees & -0.0588 & -0.137 & -0.194 \\
\hline & $(0.0924)$ & $(0.119)$ & $(0.125)$ \\
\hline
\end{tabular}


TABle 6: Continued.

\begin{tabular}{lccc}
\hline & OLS & RE & BE \\
\hline Refuges & -0.0652 & $-0.121^{* *}$ & $-0.140^{* *}$ \\
& $(0.0659)$ & $(0.0594)$ & $(0.0591)$ \\
Quebec & -0.0157 & 0.00117 & $(0.0357)$ \\
& $(0.0308)$ & $(0.0337)$ & $-0.0576^{* *}$ \\
Ontario & -0.0387 & -0.0415 & $(0.0284)$ \\
& $(0.0244)$ & $-0.0266)$ & -0.0551 \\
Western & -0.0236 & $(0.0344)$ & $0.0366)$ \\
& $(0.0327)$ & 0.101 & $(0.0574$ \\
Atlantic & 0.185 & $(0.0967)$ & $0.1139^{* * *}$ \\
& $(0.117)$ & $0.167^{* * *}$ & $(0.0232)$ \\
Male & $0.146^{* * *}$ & $(0.0221)$ & $3.710^{* * *}$ \\
Constant & $(0.0205)$ & $3.695^{* * *}$ & $(0.168)$ \\
Observations & $3.725^{* * *}$ & $(0.148)$ & 9338 \\
$R$-squared & $(0.172)$ & 9338 & \\
Number of id & 201123 & & 0.430 \\
\hline
\end{tabular}

Standard errors are in parentheses. ${ }^{* * *} P<0.01,{ }^{* *} P<0.05,{ }^{*} P<0.1$.

used in what follows. The return to over-education is $36.8 \%$ of the returns to required education for females, while for males, the return to over-education is $13.2 \%$ of the returns to required education. Over-educated males (females) earn $8.7 \%(7.6 \%)$ less than workers with the same education attainment in jobs which require that level of schooling. This means that for females there is no wage loss to an additional year of deficit schooling relative to coworkers. However under-educated males lost 3.25\% for an additional year of deficit schooling relative to coworkers. Although the return to under-education is not statistically significant for females, the effect of under-education has almost the same magnitude as for over-education. The effects of the other explanatory variables are consistent with a priori expectations. Earnings increase for immigrants with English or French as a mother tongue, and with having full-time foreign experience recognized in the Canadian labour market. Working in a parttime job naturally reduces earnings. An immigrant's earnings also increase with age and having longer Canadian work experience.

\section{Discussion}

The high incidence of over-education among recent immigrants to Canada could be explained by several reasons that are widely discussed in the literature [25]. Immigrants are forced, at least during the early period of entering the host country's labour market, to accept jobs with less educational requirement due to lack of host country-specific human capital (e.g., job experience, contacts in labour market, and language skills). Based on data from the LSIC, after four years from arrival to Canada, lack of Canadian work experience was mentioned to be the main difficulty $(49.8 \%)$, followed by lack of contacts in the job market (37.1\%), nonrecognition of foreign experience (37\%), and foreign qualifications (35.4\%). About one-third of job seekers who experienced difficulties stated language barriers as a problem. Entering the labour market during periods of recession could be a possible reason for the high incidence of over-education [27]. It is evident that the LSIC participants have arrived to Canada during a period of recession. As a result, these immigrants are left with no option other than survival jobs. About one-third of the job seekers who experienced difficulties reported lack of employment opportunities as a problem.

Costly accreditation and licensing requirements by professional associations in many regulated occupations also constitute an entry barrier in many occupations. Poor sourcecountry schooling quality is another reason for the high incidence of over-education among recent immigrants [27]. Recent data show that there has been a shift from countries with a high quality educational system to countries with a low quality educational system. According to the 2006 Canadian Census of Population, 58.3\% of recent immigrants came from Asia (including the middle-east) compared to $12.1 \%$ in 1977 , while those who came from Europe was $16.1 \%$ compared with $61.6 \%$ in 1977. Picot and Hou [28] find that Canadian employers have no reliable information about the real occupational skills and education quality of graduates from Asian institutions. Another challenge is that recent immigrants have less command of official languages. For example, only $9.5 \%$ of the immigrants in the LSIC report English or French as their mother tongue. Another reason is that there could be some discrimination in the labour market toward visible minorities. About $15 \%$ of the immigrants covered by the LSIC reported discrimination as the main difficulty in finding a suitable job. This is supported by several studies which argued that immigrants are subject to discrimination in the Canadian labour market 
TABLE 7: The earnings impact of job-education mismatch by gender.

\begin{tabular}{|c|c|c|c|c|c|c|}
\hline & \multicolumn{3}{|c|}{ Males } & \multicolumn{3}{|c|}{ Females } \\
\hline & OLS & $\mathrm{RE}$ & $\mathrm{BE}$ & OLS & RE & $\mathrm{BE}$ \\
\hline \multirow{2}{*}{ Years of required education } & $0.100^{* * *}$ & $0.0958^{* * *}$ & $0.118^{* * *}$ & $0.120^{* * *}$ & $0.115^{* * *}$ & $0.108^{* * *}$ \\
\hline & $(0.00994)$ & $(0.00789)$ & $(0.00961)$ & $(0.0110)$ & $(0.00973)$ & $(0.0122)$ \\
\hline \multirow{2}{*}{ Years of over-education } & $0.0132^{* *}$ & $0.0125^{*}$ & 0.00893 & $0.0442^{* * *}$ & $0.0386^{* * *}$ & $0.0387^{* * *}$ \\
\hline & $(0.00628)$ & $(0.00726)$ & $(0.00794)$ & $(0.00893)$ & $(0.00811)$ & $(0.00883)$ \\
\hline \multirow{2}{*}{ Years of undereducation } & $-0.0324^{* * *}$ & $-0.0405^{* * *}$ & $-0.0411^{* * *}$ & -0.0111 & -0.00451 & -0.00138 \\
\hline & $(0.0113)$ & $(0.0122)$ & $(0.0133)$ & $(0.0105)$ & $(0.0108)$ & $(0.0113)$ \\
\hline \multirow{2}{*}{ Age } & $0.0255^{* *}$ & $0.0367^{* * *}$ & 0.0136 & $0.0547^{* * *}$ & $0.0563^{* * *}$ & $0.0586^{* * *}$ \\
\hline & $(0.0104)$ & $(0.0103)$ & $(0.0116)$ & $(0.0150)$ & $(0.0107)$ & $(0.0116)$ \\
\hline \multirow{2}{*}{ Age square } & $-0.000312^{* *}$ & $-0.000417^{* * *}$ & -0.000156 & $-0.000712^{* * *}$ & $-0.000718^{* * *}$ & $-0.000763^{* * *}$ \\
\hline & $(0.000130)$ & $(0.000124)$ & $(0.000140)$ & $(0.000204)$ & $(0.000137)$ & $(0.000148)$ \\
\hline \multirow{2}{*}{ Visible minority } & $-0.162^{* * *}$ & $-0.158^{* * *}$ & $-0.146^{* * *}$ & 0.0548 & $0.0722^{*}$ & $0.0845^{* *}$ \\
\hline & $(0.0338)$ & $(0.0367)$ & $(0.0374)$ & $(0.0369)$ & $(0.0406)$ & $(0.0422)$ \\
\hline \multirow{2}{*}{ English/French is mother tongue } & $0.165^{* * *}$ & $0.182^{* * *}$ & $0.164^{* * *}$ & $0.168^{* *}$ & $0.153^{* * *}$ & $0.179^{* * *}$ \\
\hline & $(0.0393)$ & $(0.0482)$ & $(0.0500)$ & $(0.0665)$ & $(0.0546)$ & $(0.0587)$ \\
\hline \multirow{2}{*}{ Full time foreign experience } & 0.0121 & -0.0474 & 0.0209 & 0.0449 & 0.0412 & 0.0549 \\
\hline & $(0.0412)$ & $(0.0526)$ & $(0.0549)$ & $(0.0359)$ & $(0.0391)$ & $(0.0407)$ \\
\hline \multirow{2}{*}{ Foreign experience is recognized } & $0.300^{* * *}$ & $0.312^{* * *}$ & $0.298^{* * *}$ & $0.224^{* * *}$ & $0.240^{* * *}$ & $0.235^{* * *}$ \\
\hline & $(0.0297)$ & $(0.0339)$ & $(0.0354)$ & $(0.0382)$ & $(0.0419)$ & $(0.0459)$ \\
\hline \multirow{2}{*}{ Married } & 0.0432 & 0.0284 & 0.0737 & -0.0103 & -0.0137 & -0.0147 \\
\hline & $(0.0422)$ & $(0.0433)$ & $(0.0449)$ & $(0.0423)$ & $(0.0432)$ & $(0.0461)$ \\
\hline \multirow{2}{*}{ Part time } & $-1.032^{* * *}$ & $-1.048^{* * *}$ & $-1.034^{* * *}$ & $-0.935^{* * *}$ & $-0.923^{* * *}$ & $-0.958^{* * *}$ \\
\hline & $(0.0461)$ & $(0.0311)$ & $(0.0494)$ & $(0.0381)$ & $(0.0289)$ & $(0.0408)$ \\
\hline \multirow{2}{*}{ Experience in Canada } & $0.00414^{* * *}$ & $0.00382^{* * *}$ & $0.00575^{* * *}$ & $0.00333^{* * *}$ & $0.00338^{* * *}$ & $0.00340^{* * *}$ \\
\hline & $(0.000286)$ & $(0.000249)$ & $(0.000707)$ & $(0.000403)$ & $(0.000330)$ & $(0.000690)$ \\
\hline \multirow{2}{*}{ Education and recreational } & -0.0151 & -0.0716 & -0.0652 & -0.0922 & $-0.123^{*}$ & $-0.132^{* *}$ \\
\hline & $(0.0903)$ & $(0.0799)$ & $(0.0824)$ & $(0.0570)$ & $(0.0630)$ & $(0.0668)$ \\
\hline \multirow{2}{*}{ Fine art } & 0.173 & 0.100 & 0.181 & -0.134 & -0.172 & $-0.220^{*}$ \\
\hline & $(0.280)$ & $(0.145)$ & $(0.146)$ & $(0.143)$ & $(0.114)$ & $(0.116)$ \\
\hline \multirow{2}{*}{ Humanities } & -0.0448 & -0.0378 & -0.00787 & -0.0880 & -0.0631 & -0.0204 \\
\hline & $(0.0889)$ & $(0.0993)$ & $(0.101)$ & $(0.0654)$ & $(0.0640)$ & $(0.0677)$ \\
\hline \multirow{2}{*}{ Social sciences } & 0.00380 & -0.0120 & 0.000376 & -0.0942 & -0.0962 & -0.102 \\
\hline & $(0.0604)$ & $(0.0668)$ & $(0.0686)$ & $(0.0576)$ & $(0.0661)$ & $(0.0695)$ \\
\hline \multirow{2}{*}{ Commerce } & -0.00254 & -0.00422 & 0.00741 & 0.0114 & 0.00494 & 0.00494 \\
\hline & $(0.0368)$ & $(0.0504)$ & $(0.0517)$ & $(0.0465)$ & $(0.0504)$ & $(0.0532)$ \\
\hline \multirow{2}{*}{ Agriculture } & -0.147 & -0.107 & -0.0569 & -0.107 & -0.0739 & -0.00632 \\
\hline & $(0.0936)$ & $(0.114)$ & $(0.117)$ & $(0.107)$ & $(0.105)$ & $(0.109)$ \\
\hline Fngineering & 0.0307 & 0.000151 & 0.00856 & 0.00240 & 0.0108 & 0.0209 \\
\hline cngmeering & $(0.0356)$ & $(0.0468)$ & $(0.0481)$ & $(0.0605)$ & $(0.0638)$ & $(0.0673)$ \\
\hline Health & 0.0341 & 0.0779 & 0.0478 & -0.0559 & -0.0879 & -0.114 \\
\hline Hitamin & $(0.110)$ & $(0.114)$ & $(0.116)$ & $(0.0652)$ & $(0.0844)$ & $(0.0896)$ \\
\hline Mathematics & $0.199^{* * *}$ & $0.184^{* * *}$ & $0.199^{* * *}$ & $0.178^{*}$ & $0.158^{*}$ & 0.137 \\
\hline & $(0.0617)$ & $(0.0651)$ & $(0.0667)$ & $(0.100)$ & $(0.0917)$ & $(0.0972)$ \\
\hline Family class & -0.120 & $-0.145^{* *}$ & $-0.180^{* * *}$ & $0.134^{* *}$ & 0.112 & 0.0822 \\
\hline & $(0.0871)$ & $(0.0699)$ & $(0.0698)$ & $(0.0582)$ & $(0.0778)$ & $(0.0801)$ \\
\hline Skilled workers & -0.0555 & -0.0817 & -0.103 & 0.0761 & 0.0714 & 0.0579 \\
\hline & $(0.0833)$ & $(0.0677)$ & $(0.0671)$ & $(0.0566)$ & $(0.0762)$ & $(0.0781)$ \\
\hline Provincial nominees & $-0.240^{* *}$ & $-0.291^{*}$ & $-0.330^{* *}$ & 0.202 & 0.0780 & 0.0156 \\
\hline & $(0.122)$ & $(0.156)$ & $(0.163)$ & $(0.128)$ & $(0.184)$ & $(0.193)$ \\
\hline
\end{tabular}


TABle 7: Continued.

\begin{tabular}{|c|c|c|c|c|c|c|}
\hline & \multicolumn{3}{|c|}{ Males } & \multicolumn{3}{|c|}{ Females } \\
\hline & OLS & $\mathrm{RE}$ & $\mathrm{BE}$ & OLS & $\mathrm{RE}$ & $\mathrm{BE}$ \\
\hline \multirow{2}{*}{ Refuges } & -0.140 & $-0.227^{* * *}$ & $-0.248^{* * *}$ & 0.0386 & 0.0210 & 0.0187 \\
\hline & $(0.0957)$ & $(0.0791)$ & $(0.0780)$ & $(0.0800)$ & $(0.0893)$ & $(0.0899)$ \\
\hline \multirow{2}{*}{ Quebec } & 0.0334 & 0.0409 & 0.0438 & -0.0757 & -0.0495 & -0.0549 \\
\hline & $(0.0385)$ & $(0.0455)$ & $(0.0480)$ & $(0.0499)$ & $(0.0499)$ & $(0.0532)$ \\
\hline \multirow{2}{*}{ Ontario } & -0.00124 & -0.00943 & -0.00553 & $-0.0803^{* *}$ & $-0.0727^{*}$ & $-0.105^{* *}$ \\
\hline & $(0.0300)$ & $(0.0358)$ & $(0.0381)$ & $(0.0401)$ & $(0.0394)$ & $(0.0423)$ \\
\hline \multirow{2}{*}{ Western } & 0.0335 & 0.0399 & 0.00106 & -0.0800 & -0.0804 & $-0.0926^{*}$ \\
\hline & $(0.0418)$ & $(0.0464)$ & $(0.0495)$ & $(0.0506)$ & $(0.0510)$ & $(0.0543)$ \\
\hline \multirow{2}{*}{ Atlantic } & $0.337^{*}$ & $0.277^{* *}$ & 0.214 & -0.00117 & -0.0723 & -0.0772 \\
\hline & $(0.174)$ & $(0.124)$ & $(0.154)$ & $(0.0739)$ & $(0.151)$ & $(0.168)$ \\
\hline \multirow{2}{*}{ Constant } & $4.316^{* * *}$ & $4.248^{* * *}$ & $4.248^{* * *}$ & $3.148^{* * *}$ & $3.166^{* * *}$ & $3.254^{* * *}$ \\
\hline & $(0.223)$ & $(0.199)$ & $(0.226)$ & $(0.260)$ & $(0.223)$ & $(0.255)$ \\
\hline Observations & 112008 & 5192 & 5192 & 89115 & 4146 & 4146 \\
\hline$R$-squared & 0.394 & & 0.419 & 0.349 & & 0.389 \\
\hline Number of id & & 2224 & 2224 & & 1944 & 1944 \\
\hline
\end{tabular}

Standard errors are in parentheses. ${ }^{* * *} P<0.01,{ }^{* *} P<0.05,{ }^{*} P<0.1$.

(see: $[4,7,28])$ For example, Oreopoulos [29] conducted a study using thousands of resumes sent in response to online job postings for occupations in Toronto. The author finds considerable employer discrimination against applicants with ethnic names on the resume in terms of lower callback rates and interview requests, compared to those with Englishsounding names.

\section{Conclusion}

This paper attempted to measure the incidence of jobeducation mismatch, particularly over-education, examine its determinants, and estimate its impact on the earnings of recent immigrants to Canada using panel data.

Results show that two-thirds of recent immigrants to Canada are over-educated with a wage penalty of about $8 \%$. Results also show that acquisition of host-countryspecific human capital, particularly, language proficiency and education and training significantly reduces the likelihood of being over-educated. Though the time span covered by this study is short, allowing only for an assessment of initial assimilation, yet, the findings of this study could benefit policies directed to help immigrants integrate in the labour market.

\section{Appendix}

For more details see Tables 1-7.

\section{Acknowledgments}

This paper uses Statistics Canada confidential data, and the opinions expressed do not represent the views of Statistics Canada. The author would like to thank Tatyana Koreshkova and Gordon Fisher for helpful comments.

\section{References}

[1] R. M. Friedberg, "You can't take it with you? Immigrant assimilation and the portability of human capital," Journal of Labor Economics, vol. 18, no. 2, pp. 221-251, 2000.

[2] C. Green, P. Kler, and G. Leeves, "Immigrant overeducation: evidence from recent arrivals to Australia," Economics of Education Review, vol. 26, no. 4, pp. 420-432, 2007.

[3] B. R. Chiswick and P. W. Miller, "The international transferability of immigrants' human capital," Economics of Education Review, vol. 28, no. 2, pp. 162-169, 2009.

[4] D. Galarneau and R. Morissette, "Immigrants: settling for less?" Perspectives on Labour and Income, vol. 5, no. 6, statistics Canada catalogue no. 75-001-XIE, pp. 5-16, 2004.

[5] C. Li, G. Gervais, and A. Duval, "The dynamics of over qualification: Canada's underemployed university graduates," Statistics Canada Analytical Paper catalogue no. 11-621-MIE -No. 039, 2006.

[6] D. Galarneau and R. Morissette, "Immigrants' education and required job skills," Perspectives on Labour and Income, vol. 9, no. 12, statistics Canada catalogue no. 75-001-X, pp. 5-18, 2008.

[7] S. Wald and T. Fang, "Overeducated immigrants in the Canadian labour market: evidence from the workplace and employee survey," Canadian Public Policy, vol. 34, no. 4, pp. 457-479, 2008.

[8] C. P. Nielsen, "Immigrant over-education: evidence from Denmark," Journal of Population Economics, vol. 24, no. 2, pp. 499-520, 2011.

[9] J. K. Lindley and P. Lenton, "The over-education of UK immigrants: evidence from the labour force survey," Sheffield Economic Research Paper Series SERP 2006001, 2006.

[10] P. Kler, "A panel data investigation into over-education among tertiary educated Australian immigrants," Journal of Economic Studies, vol. 34, no. 3, pp. 179-193, 2007.

[11] M. C. Tsang and H. M. Levin, "The economics of overeducation," Economics of Education Review, vol. 4, no. 2, pp. 93-104, 1985. 
[12] M. C. Tsang, "The impact of underutilization of education on productivity: a case study of the U.S. Bell companies," Economics of Education Review, vol. 6, no. 3, pp. 239-254, 1987.

[13] M. Tsang, R. Rumberger, and H. Levin, "The impact of surplus schooling on worker productivity," Industrial Relations, vol. 30, pp. 209-228, 1991.

[14] The Conference Board of Canada, Performance and potential 2004-2005: key findings. How can Canada prosper in tomorrow's world?, 2004, http://www.conferenceboard.ca.

[15] M. Spence, "Job market signaling," The Quarterly Journal of Economics, vol. 87, no. 3, pp. 355-374, 1973.

[16] F. Büchel and M. van Ham, "Overeducation, regional labor markets, and spatial flexibility," Journal of Urban Economics, vol. 53, no. 3, pp. 482-493, 2003.

[17] R. H. Frank, "Why women earn less: the theory and estimation of differential overqualification," The American Economic Review, pp. 360-373, 1978.

[18] J. Hartog, "Over-education and earnings: where are we, where should we go?" Economics of Education Review, vol. 19, no. 2, pp. 131-147, 2000.

[19] J. M. Wooldridge, Econometric Analysis of Cross Section and Panel Data, The MIT Press, Cambridge, Mass, USA, 2002.

[20] C. Cameron and P. K. Trivedi, Microeconometrics Using Stata, Stata Press, 2010.

[21] B. R. Chiswick and P. W. Miller, "The effects of school quality in the origin on the payoff to schooling for immigrants," in Migration and Culture (Frontiers of Economics and Globalization), G. S. Epstein and I. N. Gang, Eds., vol. 8, chapter 4, pp. 67-103, Emerald Group, 2010.

[22] N. Sicherman, "Overeducation in the Labor Market," Journal of Labor Economics, vol. 9, no. 2, pp. 101-122, 1991.

[23] B. F. Kiker, M. C. Santos, and M. M. De Oliveira, "Overeducation and undereducation: evidence for Portugal," Economics of Education Review, vol. 16, no. 2, pp. 111-125, 1997.

[24] W. Groot and H. Maassen Van Den Brink, "Overeducation in the labor market: a meta-analysis," Economics of Education Review, vol. 19, no. 2, pp. 149-158, 2000.

[25] F. Büchel, A. De Grip, and A. Mertens, Overeducation in Europe: Current Issues in Theory and Policy, Edward Elgar, Mass, USA, 2003.

[26] Statistic Canada, "2001 census Handbook," Catalogue no. 92379-XIE, 2003, http://www12.statcan.ca/english/census01/Products/Reference/2001handbook/pdf/92-379-XIE02001.pdf.

[27] M. F. Sharaf, Essays on immigration and economic policy [Ph.D. thesis], Department of Economics, Concordia University, 2012.

[28] G. Picot and F. Hou, "The rise in low-income rates among immigrants in Canada," Analytical Studies Branch Research Paper Series catalogue no. 11F0019MIE2003198, Statistics Canada, 2003.

[29] P. Oreopoulos, "Why do skilled immigrants struggle in the labor market? A field experiment with six thousand résumés," NBER Working Paper no. 15036, 2009. 


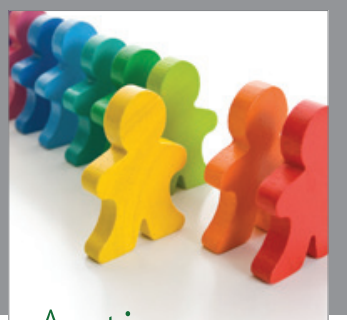

Autism

Research and Treatment
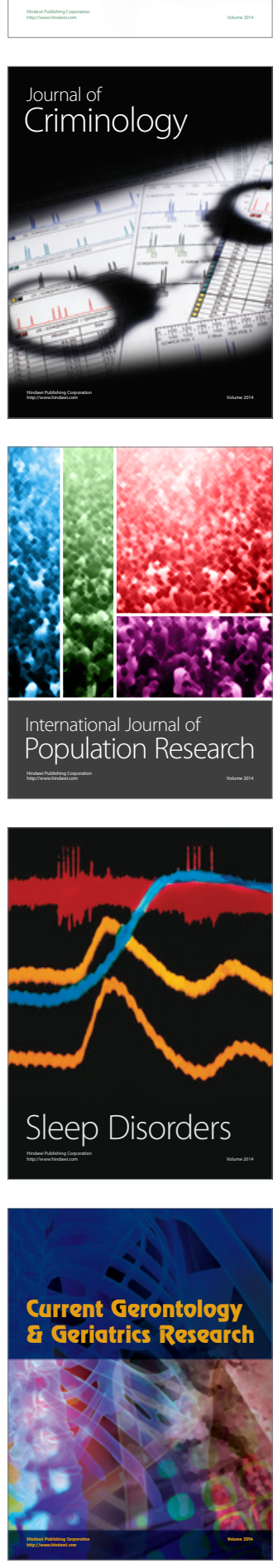
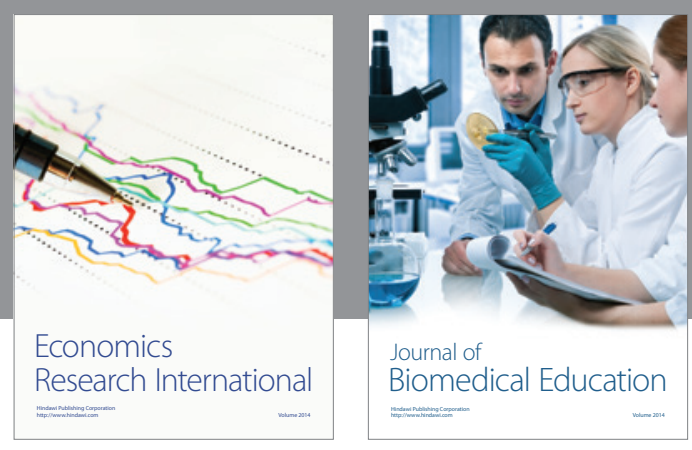

Journal of

Biomedical Education

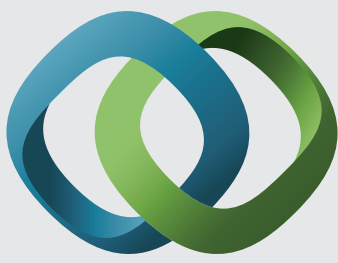

\section{Hindawi}

Submit your manuscripts at

http://www.hindawi.com
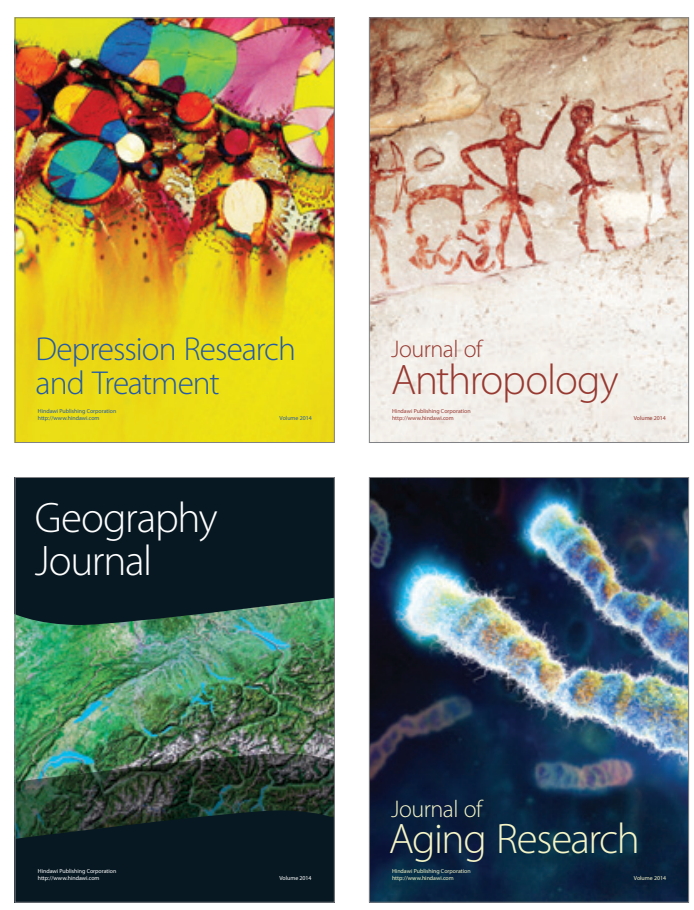

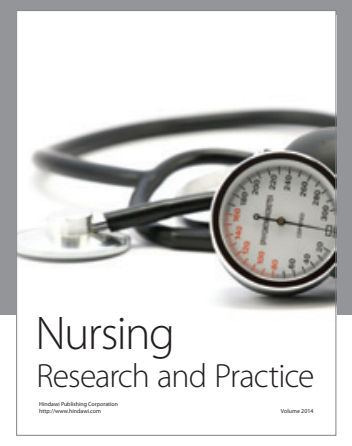

Nursing

Research and Practice

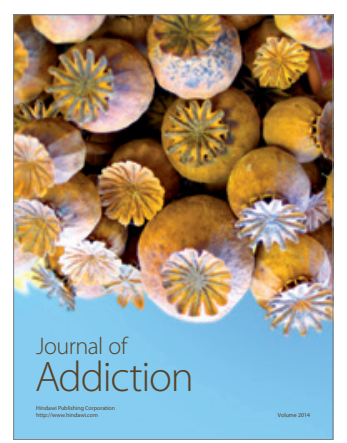

Child Development

Research

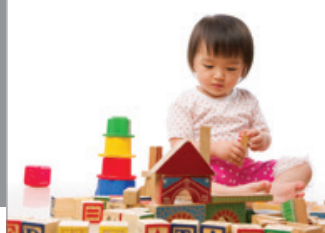

迥
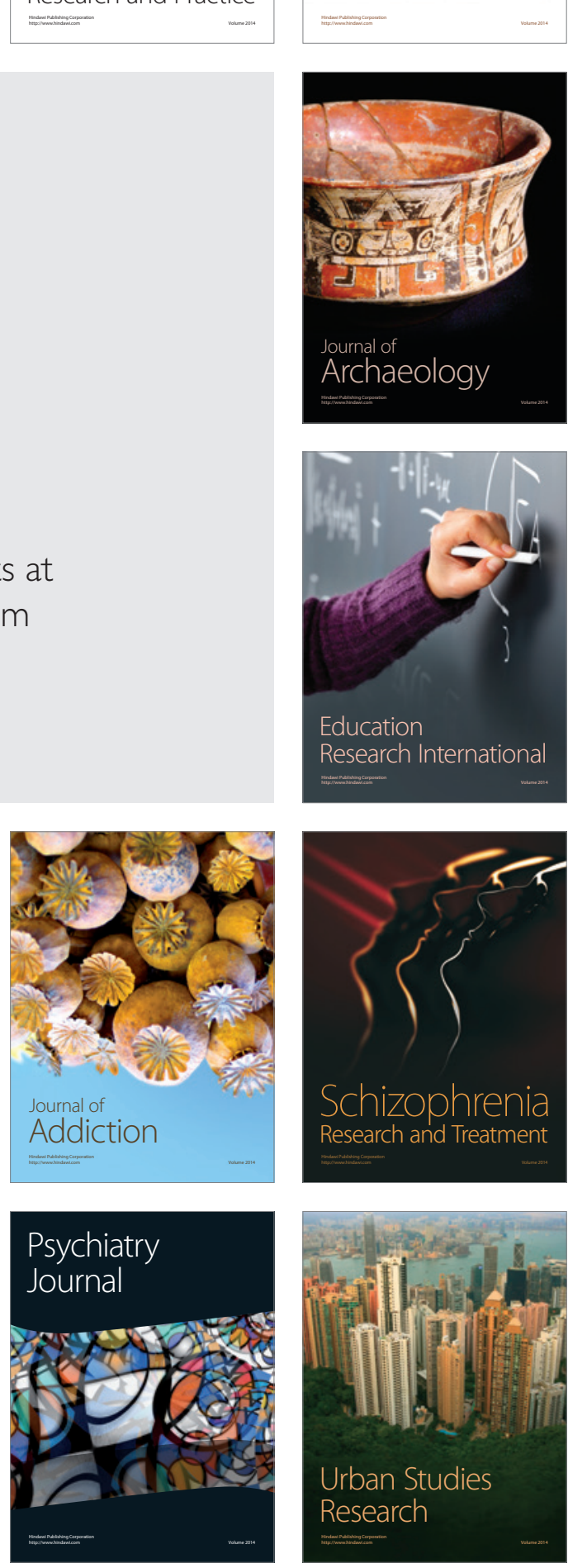